\title{
The New Lion of Damascus
}





\title{
The New Lion of Damascus
}

\author{
Bashar al-Asad and Modern Syria
}

\author{
David W. Lesch
}

Yale University Press

New Haven and London 
Copyright $\odot 2005$ by David W. Lesch

All rights reserved. This book may not be reproduced in whole or in part, in any form (beyond that copying permitted by Sections 107 and 108 of the U.S. Copyright Law and except by reviewers for the public press), without written permission from the publishers.

For information about this and other Yale University Press publications, please contact:

U.S. Office: sales.press@yale.edu yalebooks.com

Europe Office: sales@yaleup.co.uk www.yalebooks.co.uk

Set in Minion by J\&L Composition, Filey, North Yorkshire

Printed in Great Britain by St Edmundsbury Press Ltd, Bury St Edmunds

Library of Congress Cataloging-in-Publication Data

Lesch, David W.

The new Lion of Damascus: Bashar al-Asad and modern Syria/

David W. Lesch.- - 1st ed.

p. cm.

Includes bibliographical references and index.

ISBN 978-0-300-10991-7 (cl.: alk. paper)

1. Syria-Politics and government-2000-2. Assad, Bashar, 1965-

I. Title.

DS98.6.L47 2005

956.9104' 2 - dc22

2005011804

A catalogue record for this book is available from the British Library.

10987654321 